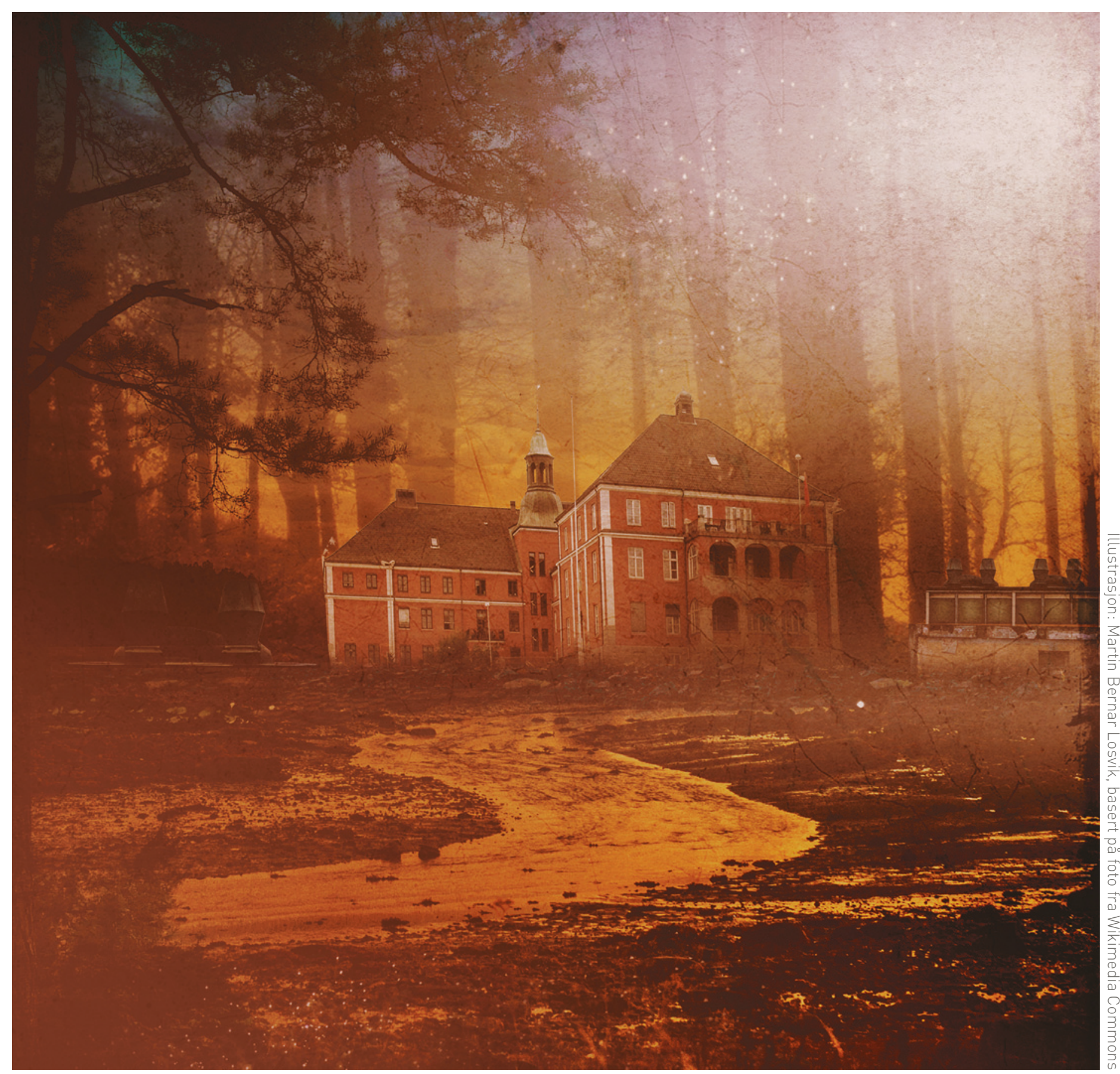

\title{
Sykehuset i Elverum
}

(i)

«Alle fikk et sterkt inntrykk av dette store, moderne utstyrte og praktisk innredete anlegg. I mangt og meget minnet det mer om et hyggelig og vakkert utstyrt hjem enn et sykehus», skrev Østlendingen etter åpningen av Elverum sykehus 12. september 1925. Sykehuset hadde altså 90 -årsjubileum i 2015. Gjennom denne perioden har den medisinske utviklingen vært enorm. I 1925 lå pasientene på sykehuset i gjennomsnitt 28 døgn. I dag er tilsvarende tall 2,8. 